\title{
Determinants of Value Creation in Cross-Border M\&As: The Case of the Software Industry
}

\author{
Alberto Pezzi ${ }^{1}$ \\ ${ }^{1}$ Dept. Business Studies, University Roma Tre, 00145 Rome, Italy \\ Correspondence: Alberto Pezzi, Dept. Business Studies, University Roma Tre, 00145 Rome, Italy. E-mail: \\ alberto.pezzi@uniroma3.it
}

Received: February 16, 2018

Accepted: March 6, 2018

Online Published: March 18, 2018

doi:10.5539/ijbm.v13n4p183

URL: https://doi.org/10.5539/ijbm.v13n4p183

\begin{abstract}
This study specifically focuses on the software market and tries to identify the sources that intensify equity investments through merger and acquisition (M\&A) paths. Increasing the firm size and accessing new growth opportunities is particularly significant in the software industry. Consistent with this view, this work focuses on the cross-border strategies that could be used to manage value creation processes. The results found are based on the fact that diversification of the geographic market (acquiring cross-border technology) is relevant to the positive answers given by the stock markets. Moreover, the age of the target firm strongly influences M\&A decisions and the younger the target firm is, the higher the possibility of creating value, but this variable increases uncertainty in the evaluation of the target firm, decreasing the purchase offers. The complementary nature between the acquiring and the target firm and the size of the investing firm influence market return and appear to be linked. These results provide empirical evidence on the use of financial measures to determine the goodness of an acquisition but, above all, they provide a new reading of the evaluation of the complementary nature between the buyer and the target firm.
\end{abstract}

Keywords: value creation, software industry, mergers and acquisitions, acquisition timing

\section{Introduction}

The software market has continually grown over the past ten twenty years and by 2017, software spending will have grown by $6.2 \%$ in Western Europe (Gartner (2017). Innovation, new technologies and new process developments have facilitated entry into the market of new competitors and have dramatically reduced firms' profits with a subsequent intensification of aggressive acquisition programs.

Equity investments such as mergers and acquisitions (M\&As), joint ventures and minority stakes purchases can be viewed in a double prospective. Equity investments play an important role in the product development process (Higgins \& Rodriguez, 2006). Large firms use aggressive acquisition programs to accelerate their internal research and development because time-to-market is crucial in high-technology industries. Acquisitions help mature firms to access new growth opportunities and ideas (Autio, Sapienza \& Almeida, 2000), complete product portfolios (Ding \& Eliashberg, 2002) and obtain complementary downstream activities in the new product development process (Kleis, Chwelos, Ramirez \& Cockburn, 2012). At the same time, M\&As are the quickest way to increase market share and power in the software industry without waiting years to pay off marketing and sales expenditures.

Equity investments activities do not often add value to the acquirer because the potential synergies, planned before the two businesses are combined, could be compromised by technological integration problems. Post-M\&A integration problems can be severe in cross-border acquisitions when technological integration difficulties are linked to differences in culture, values and norms (Morresi \& Pezzi, 2014).

Value creation through cross-border investments has received limited attention in the software industry (Ransbotham \& Mitra, 2010). This study analyzes cross-border deals in a sample of software firms listed on European stock exchanges in order to answer the following questions: in the software industry, do cross-border deals create positive returns for acquiring firms? What are the determinants of value creation? The work analyzes the effect of characteristics of a target firm in high-technology environments on buyer performance: specifically, target age, size, diversification and the level of complementarity between the acquirer and the target firm. 
Country-specific determinants such as entry mode, cultural distance, the country of destination, and country risk are examined to understand their incidence on value creation. The methodologies adopted in the study are: the event study methodology to investigate stock market reaction to cross-border announcements and an OLS regression to determine the determinants of value creation.

Contributions made by this research work are: first, it analyzes the capabilities of software firms to create value through cross-border acquisition. Second, the study investigates the impact of characteristics of the target firms on value creation and on the acquirer trade-off between buying the target firm earlier to have rapid access to innovation/technologies and moderate post-acquisition integration difficulties or delaying the acquisition of the target firm when information asymmetries are lower and the price is higher. Third, I also provide empirical evidence on the effect of country-specific determinants on value creation.

The paper is organized as follows: Section 2 provides a theoretical background and develops hypotheses on value creation through cross-border strategies in the software industry; Section 3 details the sample data and methodology utilized to test hypotheses; Section 4 discusses the results of the analysis; finally, Section 5 provides some conclusions and underlines the main limitations of the study.l

\section{Literature Review and Hypotheses Development}

In high-speed environments, characterized by innovation and technological change (Brown \& Eisenhardt, 1997; Schmalensee, 2000), international expansion is a strategic choice to rapidly enter new markets and acquire customers and/or complement internal R\&D efforts. Software firms can easily be the object of takeovers because they are not physically confined by nature. The development of the M\&A market is driven by the hyper competition of the software industry (D'Aveni \& Gunther, 1994) which generates high instability in revenues, market shares and performance for firms (Baldwin \& Clark, 2000) and uncertainty over which technologies will dominate the environment in the future. The M\&A market consists of a large number of young, attractive firms which focus on technology development and consider being a target firm to be a good exit strategy. From the acquirer's perspective, young firms have the potential to generate profits, a generally lower cost of acquisition and integration problems. However, the acquirer valuation of the young target firm is strictly dependent on market uncertainty and technology uncertainty (Warner, Fairbank, Steensma, 2006). When a target firm becomes older, the lower valuation of uncertainty means a higher cost of acquisition and lower synergies because its technology becomes more mature (Ransbotham \& Mitra, 2010). To determine the starting target date, several sources were consulted: the Amadeus database, the company profile on its website or in financial reports and press releases on the acquisition. Therefore, I hypothesize:

$\mathrm{H} 1$ : Value creation is negatively associated with the target firm's age.

Over the past ten years, software firms have heavily invested abroad to open up new opportunities for rapid growth and development of new technologies or products which acquirers have not yet fully exploited. The entry into international markets of new competitors has reduced firms' returns with a consequent intensification of mergers and acquisitions. A firm's survival and profitability within an industry can be reached through related diversification strategies (Stern \& Henderson, 2004; Li \& Greenwood, 2004). In the software industry in particular, acquisitions in related businesses are used to decrease rivalry or rapidly obtain various forms of innovation such as technology, intellectual property, know how, etc. from the firm that generated it.

The software industry is characterized by firms specialized in a well-defined business that depend on other companies to offer complementary components. The presence of multinational incumbents such as Microsoft in operating systems, Oracle in middleware, SAP, IBM etc. drive the market in their industry segment (layer, to use software architecture terminology) and influence firms, in other segments, to create components that may have to be used together and systems that have to be interoperable. When components complement each other, producers are incentivized to promote interoperability between players and enter into complementary markets through partnerships, alliances or equity entry modes (Gerstner, 2003; Milgrom \& Roberts, 1990). Therefore, the return gained from the combination of the activities is higher than the sum of the returns for the single activities. Following the resource-based view (Barney, 1991), the complementary nature of products and services is more valuable, rare, inimitable, and harder to substitute than a firm's specific asset. This complementary nature creates a mutual dependency between firms that influences their performance and can be transformed into a source of value creation (Lee, Venkatraman, Tanriverdi \& Iyer, 2010; Tanriverdi \& Venkatraman, 2005). In the applications software segment, for example, complementary products provide access to larger networks if users have the need to share files and enable a firm to benefit from network externalities, increasing its sales and market share (Tanriverdi \& Lee, 2005). Consumers benefit from utilizing complementary products through a common platform and firms gain a competitive advantage if they have the ability to create integrated platforms 
that can be associated with high switching costs for users (Porter \& Siggelkow, 2008). The advantages that could be gained when complementary products benefit from a partners' customer base or help the product development process can be critical for realizing positive returns in related diversification strategies. Re-examining Gao and Iyer (2006), the work divides the software industry into the following five different segments: hardware industry; application software; middleware software (connects software components or applications); system software (containing principally operating, network and database management systems) and the service industry. I include the service and hardware industry as possible complementary segments of software firms. To explore the relationship between value creation and the complementary nature of the cross-border deal, the study considers each segment according to the complementary segment above and below. I define the complementary segment as the distance from two different segments in a strict order of relations. To reflect an increasing scale of relatedness, I have used 4-digit level SIC codes. The distance generates values between 0 and 1 where 0 is the lowest distance between the acquirer and the target firm. In this case, the segment of the acquirer matches the segment of the target firm and their activities are considered similar. The distance increases with the proportion of revenues that the target firm gains in software, service or hardware segments. The more revenues in service or hardware segments the target gains, the larger the distance between the acquirer and the target firm. The value of the distance is 1 when the acquirer-software firm invests a target firm that is exclusively in the hardware or service segment. Previous statements imply the subsequent hypothesis:

$\mathrm{H} 2$ : Value creation is positively associated with complementary cross-border deals.

However, it is an open question if related diversification generates better performance than unrelated diversification. In literature, mixed empirical results can be found. Advantages of unrelated diversification can be outlined in the co-insurance effect (Stein, 1997; Doukas \& Kan, 2008); when diversification produces cash flow stabilization, gains balance losses and vice versa. The characteristics of the software industry associated with the evolution of the technology may provide new opportunities for software firms to access unrelated businesses. Conversely, other researchers have found an increase in agency costs in the case of unrelated diversification mainly caused by the inefficiency of the internal capital market (Shin \& Stulz, 1998; Rajan, Servaes \& Zingales, 2000). In the software industry, diversification facilitates competition when it is oriented to allow acquirers to fill gaps in their portfolio of products or add ideas to product development. A 4-digit level SIC code is used to determine the industry relatedness and answer the subsequent hypothesis:

$\mathrm{H}$ 3:Value creation is positively associated with cross-border deals in related industries.

When analyzing cross-border deals, it is important to examine the entry mode as an independent variable. In literature, a huge amount of empirical work has found mixed results on the relationship between performance and entry modes in foreign countries (Ahern \& Weston 2007). Following. the transaction cost theory, the entry mode decision, for the acquirer, is an efficient economic solution in a condition of risk and external uncertainty between the resources needed to accomplish the investment and costs associated with management and control of transactions (Brouthers, Brouthers \& Werner, 2003; Zhao, Luo \& Suh, 2004).

In the software industry, several reasons can validate a firm's choice to create value through cross-border M\&A decisions: from economies of scale and scope to market share growth; from extending technological capabilities, new capabilities and managerial skills to taking advantage of first mover benefits, etc. However, the waves of technological acquisitions in the software industry are also explained by behavioral theories of M\&As that justify the proliferation on deals and consequent value destruction with stock market misevaluations, hubris, agency and integration problems (Uhlenbruck, Hitt \& Semadeni, 2006).

Value creation is also dependent on the percentage of the target firm that is acquired by the acquirer. Zaheer, Castaner and Souder (2005) argued that the percentage acquired is a proxy for the degree of integration. They found negative performance when product complementarities and business similarities are related with low degrees of integration. The performance becomes more positive when the percentage of the target firm acquired increases. To answer the following research hypothesis, I divide equity entry modes into two categories: high-equity entry modes that includes mergers and acquisitions and low-equity entry modes that include minority stakes purchases in foreign companies:

H4: Value creation is positive and generates higher gains in mergers and acquisitions than in the purchase of minority stakes.

I included two control variables for acquisition size. First, I constructed the relative size of the target firm as the ratio between the price of the deal and the market capitalization of the acquirer to analyze if value creation increases in relationship to the relative size of the target firm as reviled by previous researches (Asquith, Bruner \& Mullins, 1983; Jarrell \& Poulsen, 1989). Second, I also analyze the size of the acquirer. In the literature, 
Moeller, Schlingemann and Stulz (2004) found that smaller acquiring firms perform better than larger ones. I calculate the size of the acquirer as the market capitalization of the acquirer before the cross-border deal to answer the subsequent hypothesis:

H5a: Value creation is positively associated with the relative size of the target firm.

$\mathrm{H} 5 \mathrm{~b}$ : Value creation is negatively associated with the size of the investing firm.

Other control variables are linked to the characteristics of the country of destination. A cross-border deal also incorporates investment risks associated with different host countries' economic, legal, political, and cultural systems, as well as market attractiveness. The level of development in the country of destination is considered an important proxy of value creation. I divide the country of destination into two categories: advanced countries and emerging/developing countries, following the classification proposed by the International Monetary Fund. Usually, emerging markets are more exposed to risk because they are more susceptible to unexpected changes in the political and institutional environment, the stock? exchange and the interest rate policy. However, it is possible to enter emerging countries with a low country risk such as China, Poland and Hong Kong. This means that the level of development and the country risk seized is similar to characteristics in the country of destination and should be treated individually (Van Agtmael \& Errunza, 1982). To analyze the country risk, I use the rating scores issued by Standard \& Poor's. Using data collected from the International Monetary Fund, the study also analyzes the attractiveness of the country of destination through the level of GDP per capita. In high-technology industries in particular, this variable mitigates the effects of country risk, cultural distance, and national cultural values and increases the attractiveness of the country. A study by Rothaermel, Kotha, and Steensma (2006) shows that US Internet firms prefer a country of destination with a high level of GDP per capita. Other studies support the view that small and medium firms focus primary on host countries with a low geographic distance and then on GDP per capita (Moen, Gavlen \& Endresen, 2004;Coviello \& Munro, 1997; Pezzi, 2012).

Risks, barriers, institutional gaps, liability of foreignness (Zaheer, 1995), psychic distance (Johanson \& Vahlne, 1977) and costs associated with cross-cultural integration increase with growing cultural differences between individuals and companies (Kogut \& Singh, 1988; Shenkar, 2001). Prevailing research in international business tends to emphasize the negative side of cultural distance (see Stahl \& Tung, 2015 for a complete literature review). The negative implications of cultural differences are corroborated by the poor performance of cross-border M\&As (House, Hanges, Javidan, Dorfman \& Gupta, 2014) or the loss of effectiveness when cultural borders are crossed (Trompenaars \& Hampden-Turner, 1997). From another point of view, other existing theoretical perspectives theorize the positive aspects of cross-border deals. Cross-border deals are potentially more valuable when the acquiring firm enters a culturally distant country. Differences in cultures help the acquirer to access different routines and repertoires that are missing in its own national culture (Morosini, Shane \& Singh 1998), overcome inertia, foster innovation and learning, and develop richer knowledge structures (Barkema \& Vermeulen, 1998; Vermeulen \& Barkema 2001). This mechanism has the prospective to improve the firm's competitive advantage and performance. In this work, cultural distance is calculated on the basis of the differences in country scores among all Hofstede's dimensions of national culture (Hofstede, 2001).

The research hypothesis to be tested is:

H6: Country-specific determinants affect an acquirer's value creation.

\section{Methodology and Data}

The sample includes 204 deals announced by software firms listed in European stock exchanges during the period 2001-2010. Announcements are distributed by stock exchange as follows: London stock exchange (32\%); Frankfurter Wertpapierbörse (32\%), Euronext Paris (27\%) and other European stock exchanges (9\%).

The sample includes cross-border mergers and acquisitions (73\%) and minority stake purchases (27\%).

Target firms are high technology firms that cover the following sectors according to SIC codes: software $(60 \%)$, computer services $(12 \%)$, information retrieval services $(7 \%)$, hardware and equipment technology $(6 \%)$, others (15\%). Target firms come mainly from the US (34\%), France (7\%), Germany $(6 \%)$, the UK $(6 \%)$, and the Netherlands (6\%). The majority of deals involves European firms (52\%).

The stock market response to the announcement of equity cross-border deals is carried out through the event study methodology, using the simple market model. According to Brown and Warner (1985), I estimate the abnormal returns and their statistical significance (Mikkelson and Partch1988) during the event announcement period. The study analyzes daily return, using three event windows: $(-5,+5),(-5,+1),(-1,+1)$ and a 300 day estimation period, from day -340 to day -41 . I collected information regarding cross-border announcements from Bloomberg, completing the dataset with information on deal prices obtained from Lexis-Nexis. Financial data on 
stock market returns and indexes were collected from Datastream, Thomson Financial.

\section{Results and Discussion}

Table 1 shows the results of the event study analysis on windows: $(-5,+5),(-5,+1),(-1,+1)$. The cumulative average abnormal return (CAAR) is positive (from $1.2 \%$ to $1.5 \%$ depending on the event window) and statistically significant for the whole sample. Results are not consistent with previous research (Kohers \& Kohers, 2000, Fee \& Thomas, 2004) which indicates zero or negative abnormal returns for acquirers. Investors seem to appreciate announcements of cross-border deals driven by software firms. Value creation is higher for firms listed on the London Stock Exchange $\left(\mathrm{CAAR}_{-1,+1} 2.8 \% ; 1 \%\right.$ significance level). Firms listed on Frankfurter Wertpapierbörse and Euronext Paris provide a positive abnormal return but this is not statistically significant. The results show a percentage of positive cumulative abnormal returns that is higher than $50 \%$ for the whole sample for the majority of stock exchanges with the exception of Frankfurter Wertpapierbörse. These results are also confirmed using windows $(-5,+5)$ and $(-5,+1)$.

Table 1. Abnormal returns

\begin{tabular}{|c|c|c|c|c|}
\hline \multicolumn{5}{|l|}{ Whole sample and country of acquirer } \\
\hline$(-1,+1)$ & CAAR & t-test & & Percentage of positive CARs \\
\hline Whole sample - 204 events & 0.012194 & 3.121772 & $* * *$ & $54.4 \%$ \\
\hline London Stock Exchange- 65 events & 0.028986 & 3.787105 & $* * *$ & $64.6 \%$ \\
\hline Euronext Paris - 56 events & 0.005672 & 0.758523 & & $53.6 \%$ \\
\hline Frankfurter Wertpapierbörse - 65 events & 0.005084 & 0.277312 & & $43.1 \%$ \\
\hline$(-5,+5)$ & CAAR & t-test & & Percentage of positive CARs \\
\hline Whole sample - 204 events & 0.014688 & 2.209703 & $* *$ & $52.4 \%$ \\
\hline London Stock Exchange- 65 events & 0.022187 & 2.920030 & $* *$ & $64.6 \%$ \\
\hline Euronext Paris - 56 events & 0.009029 & 0.696020 & & $54.6 \%$ \\
\hline Frankfurter Wertpapierbörse - 65 events & 0.006598 & 0.380775 & & $40.1 \%$ \\
\hline$(-5,+1)$ & CAAR & t-test & & Percentage of positive CARs \\
\hline Whole sample - 204 events & 0.0152074 & 2.650372 & $* *$ & $54.4 \%$ \\
\hline London Stock Exchange- 65 events & 0.0218991 & 2.518700 & $*$ & $62.6 \%$ \\
\hline Euronext Paris - 56 events & 0.0089587 & 0.300850 & & $56.6 \%$ \\
\hline Frankfurter Wertpapierbörse - 65 events & 0.0092774 & 0.587593 & & $42.1 \%$ \\
\hline
\end{tabular}

Note. ${ }^{* * *}$ denotes significance at $1 \%$ level, ${ }^{* *}$ denotes significance at $5 \%$ level, $*$ denotes significance at $10 \%$ level.

OLS regression was conducted in order to determine the determinants of value creation.

Table 2. OLS regression

\begin{tabular}{llll}
\hline & Coeff. & Std. Error & t-test \\
\hline Const & 0,160332 & 0,022461 & $7,1382 * * *$ \\
Age of target firm & $-0,00836635$ & 0,000991316 & $-8,4396 * * *$ \\
$\%$ target acquired & 0,00125372 & 0,00406678 & 0,3083 \\
Diversification & $-0,00434277$ & 0,00581611 & $-0,7467$ \\
Complementary & $-0,01558$ & 0,00917577 & $-1,6980 *$ \\
Country risk & 0,00789874 & 0,0155276 & 0,5087 \\
Cultural distance & $-9,41986 \mathrm{e}-05$ & 0,000118113 & $-0,7975$ \\
Level of development & $-0,00835344$ & 0,0122903 & $-0,6797$ \\
Relative size & 0,00204738 & 0,00452483 & 0,4525 \\
Size & $-0,0050804$ & 0,00201173 & $-2,5254 * *$ \\
\hline
\end{tabular}

Note. Dependent variable CAR $(-1,+1) ; R^{2}$ adjusted 0,420323; Observations n. 204; *** denotes significance at $1 \%$ level, $* *$ denotes significance at $5 \%$ level, $*$ denotes significance at $10 \%$ level. 
Table 2 shows the results with the market-adjusted model (Fuller, Netter, Stegemoller, 2002), using the window $(-1 ;+1)$ abnormal return as the dependent variable. The model include all control variables. The target age (using a natural $\log )$ is negative and significant $(=-.00836, \mathrm{p}<001)$. The result is consistent with hypothesis 1 and indicates that an increase in target age decreases the abnormal return.

Moving on to target characteristics, regression results confirm hypothesis 2 on the significance of the complementary nature of the deal $(=-.01558, \mathrm{p}<010)$. Value creation is higher in cross-border deals where targets occupied the same or complementary software segments of acquirers. Unfortunately, the coefficient for the diversification in highly related industries is consistent with hypothesis 3 but not significant. The findings also provide strong support for the relation between the complementary nature of the deal and the size of the investing firm. According to the literature, the firm size has a negative and significant impact on stock returns which is consistent with hypothesis $5 \mathrm{~b}$. Contrary to expectations and previous research, the coefficient of relative size of the deal is higher for large deals, but the non-significant result means that general conclusions cannot be drawn

With reference to country-specific determinants, expansion in richer countries with a lower cultural distance appears to have a positive impact on value creation but is not significant. The result appears to be strongly affected by geographical proximity because most announcements involve European target countries $(52 \%)$, but at the same time, indicates that the country-specific characteristics are incorporated into the selling price of the target firm.

\section{Conclusions}

This work indicates that investors seem to appreciate international deals carried out by software firms in foreign countries. Abnormal returns are positive and statistically significant for the buyer in the whole sample. Using event study methodology to measure gain from acquisitions, I evaluate the effective single performance of the deal on the acquirer firm, even if the firm makes several acquisitions or acquires small-size target firms. In the short term, it is difficult to value the gain of an acquisition by assessing accounting metrics, whereas stock market response can exploit the future benefits of the cross-border investments. It is particularly important in the software industry, in which, also according to our sample, large firms frequently acquire more than one firm per year or the technology/idea of young firms. The findings show that the age of the target firm seems to strongly affect value creation. The age of the target firm has a negative and significant impact for the acquirer, demonstrating that acquirers consider young target firms to be a greater opportunity to create value that can compensate for the uncertainty that characterizes young target firms in an early stage. According to Ransbotham and Mitra (2010), investors appear to recognize the opportunity for lower bids and a lower selling price.

Similar considerations can be drawn from the size of the acquirer which has a negative and significant impact on value creation. The flexibility of smaller firms permits a better evaluation of market opportunities and reduces the structural inertia of larger firms that have more mature and defined processes and practices. In addition, the size of the investing firm seems to interact with the complementary nature between the acquirer and the target firm. Complementarity has a negative and significant impact on value creation and deals between companies that are in contiguous sector segments, receive higher returns than deals between firms that are in distant segments of the software industry. Overall, findings indicate that acquirers rely on the innovation or technology of the target firms for complementary activities in the product development process.

The study does not find significant results that value creation is affected by the country of destination and cultural distance. Our results appear to be strongly influenced by geographical proximity because most announcements involve European target firms.

Further research improvements are related to several limitations that can be considered opportunities for future research. First, the sample size is limited and can be enlarged by expanding the time period so that we can also understand if technology or financial shocks affect results. Second, the use of other variables such as R\&D intensity, the number of patents, international market experience, the nationality of managers in the investing firm, etc., could enhance the work. Finally, to test the generalizability of these findings, other methodologies must be associated with the event study. Event study analysis demonstrates the advantages of acquiring early in the short term. The use accounting measures can be useful for understanding if the advantages of acquiring early that I found in this research work can be translated into long-term sustainable advantages. It is particularly important in the software industry in which acquisition activity is very high in order to overcome uncertainties, increase firm size and access new growth opportunities. In this condition, the expected benefits of acting quickly can outweigh a correct valuation of the risks of a rapid acquisition. 


\section{References}

Ahern, K., \& Weston, F. (2007). M\&As: The good, the bad, and the ugly. Journal of Applied Finance, 17(1), $5-20$.

Asquith, P., Bruner, R., \& Mullins, D. (1983). The gains to bidding firms from merger. Journal of Financial Economics, 11(1-4), 121-139. https://doi.org/10.1016/0304-405X(83)90007-7.

Autio, E., Sapienza, H. J., \& Almeida, J. G. (2000). Effects of age at entry, knowledge intensity, and imitability on international growth. Academy of Management Journal, 43(5), 909-924. https://doi.org/10.2307/1556419

Baldwin, C. Y., \& Clark, K. M. (2000).Design Rules: The Power of Modularity. Cambridge, MA:MIT Press.

Barkema, H. G., Bell, J. H., \& Pennings, J. M. (1996). Foreign entry, cultural barriers, and learning. Strategic Management Journal, 151-166. https://doi.org/10.1002/(SICI)1097-0266(199602)17:2<151::AID-SMJ799>3.0.CO;2-Z

Barney, J. (1991). Firm resources and sustained competitive advantage. Journal of Management, 17(1), 99-120. https://doi.org/10.1177/014920639101700108

Brouthers, K. D., Brouthers, L. E., \& Werner, S. (2003). Transaction cost-enhanced entry mode choices and firm performance. Strategic Management Journal, 24(12), 1239-1248. https://doi.org/10.1002/smj.362

Brown, S. J., \& Warner, J. B. (1985). Using daily stock returns: The case of event studies. Journal of Financial Economics, 14(1), 3-31. https://doi.org/10.1016/0304-405X(85)90042-XGet rights and content.

Brown, S. L., \& Eisenhardt, K. M. (1997). The art of continuous change: Linking complexity theory and time-paced evolution in relentlessly shifting organizations. Administrative Science Quarterly, 1-34. https://doi.org/10.2307/2393807

Coviello, N., \& Munro, H. (1997). Network relationships and the internationalisation process of small software firms. International Business Review, 6(4), 361-386. https://doi.org/10.1016/S0969-5931(97)00010-3

D’Aveni, R. A., \& Gunther, R. (1994).Hypercompetition: Managing the Dynamics of Strategic Maneuvering. New York: Free Press.

Ding, M., Eliashberg, J. (2002). Structuring the new product development pipeline. Management Science, 48(3), 343-363. https://doi.org/10.1287/mnsc.48.3.343.7727

Doukas, J. A., \& Kan, O. B. (2008). Investment decisions and internal capital markets: Evidence from acquisitions. Journal of Banking \& Finance, 32(8), 1484-1498. https://doi.org/10.1016/j.jbankfin.2007.05.017

Fee, C. E., \& Thomas, S. (2004). Sources of gains in horizontal mergers: evidence from customer, supplier, and rival firms. Journal of Financial Economics, 74(3), 423-460. https://doi.org/10.1016/j.jfineco.2003.10.002

Fuller, K., Netter, J., \& Stegemoller, M. (2002). What do returns to acquiring firms tell us? Evidence from firms that make many acquisitions. The Journal of Finance, 57(4), 1763-1793. https://doi.org/10.1111/1540-6261.00477

Gao, L. S., \& Iyer, B. (2006). Analyzing complementarities using software stacks for software industry acquisitions. Journal of Management Information Systems, 23(2), 119-147.

Gartner, (2017). Top Strategic Predictions for 2018 and Beyond: Pace Yourself, for Sanity's Sake.

Gerstner, L. V. (2003). Who Says Elephants Can't Dance? Inside IBM's Historic Turnaround. New York, NY: Harper Business.

Higgins, M. J., \& Rodriguez, D. (2006). The outsourcing of R\&D through acquisitions in the pharmaceutical industry. Journal of Financial Economics, 80(2), 351-383. https://doi.org/10.1016/j.jfineco.2005.04.004

Hofstede, G. (2001). Culture's consequences: Comparing values, behaviors, institutions, and organizations across nations (2nd ed.). Thousand Oaks, CA: Sage.

House, R. J., Hanges, P. J., Javidan, M., Dorfman, P. W., \& Gupta, V. (2004). Culture, leadership, and organizations: The Globe study of 62 societies. Thousand Oaks, CA: Sage.

Jarrell, G. A., \& Poulsen, A. B. (1989). The returns to acquiring firms in tender offers: Evidence from three decades. Financial Management, 12-19. https://doi.org/10.2307/3665645

Johanson, J., \& Vahlne, J. E. (1977). The internationalization process of the firm-a model of knowledge development and increasing foreign market commitments. Journal of International Business Studies, 8(1), 


\section{3-32. https://doi.org/10.1057/palgrave.jibs.8490676}

Kleis, L., Chwelos, P., Ramirez, R. V., \& Cockburn, I. (2012). Information technology and intangible output: The impact of IT investment on innovation productivity. Information Systems Research, 23(1), 42-59.

Kogut, B., \& Singh, H. (1988). The effect of national culture on the choice of entry mode. Journal of international business studies, 19(3), 411-432. https://doi.org/10.1057/palgrave.jibs.8490394

Kohers, N., \& Kohers, T. (2000). The value creation potential of high-tech mergers. Financial Analysts Journal, 56(3), 40-51. https://doi.org/10.2469/faj.v56.n3.2359

Lee, C. H., Venkatraman, N., Tanriverdi, H., \& Iyer, B. (2010). Complementarity-based hypercompetition in the software industry: Theory and empirical test, 1990-2002. Strategic Management Journal, 31(13), 1431-1456. https://doi.org/10.1002/smj.895

Li, S. X., \& Greenwood, R. (2004). The effect of within-industry diversification on firm performance: Synergy creation, multi-market contact and market structuration. Strategic Management Journal, 25(12), 1131-1153. https://doi.org/10.1002/smj.418

Mikkelson, W. H., \& Partch, M. M. (1988). Withdrawn security offerings. Journal of Financial and Quantitative Analysis, 23(2), 119-133. https://doi.org/10.2307/2330876

Milgrom, P., \& Roberts, J. (1990). The economics of modern manufacturing: Technology, strategy, and organization. The American Economic Review, 511-528.

Moeller, S. B., Schlingemann, F. P., \& Stulz, R. M. (2004). Firm size and the gains from acquisitions. Journal of financial economics, 73(2), 201-228. https://doi.org/10.1016/j.jfineco.2003.07.002.

Moen, Ø., Gavlen, M., \& Endresen, I. (2004). Internationalization of small, computer software firms: Entry forms and market selection. European Journal of Marketing, 38(9/10), 1236-1251. https://doi.org/10.1108/03090560410548951

Morosini, P., Shane, S., \& Singh, H. (1998). National cultural distance and cross-border acquisition performance. Journal of international business studies, 29(1), 137-158. https://doi.org/10.1057/palgrave.jibs.8490029

Morresi, O., \& Pezzi, A., (2014). Cross-border mergers and acquisitions. New York, NY: Palgrave McMillan.

Pezzi, A. (2012). Stock Market Performance and Internationalization Strategies. An Empirical Analysis of the Software Industry. World Review of Business Research, 2(6), 169-181.

Porter, M., \& Siggelkow, N. (2008). Contextuality within activity systems and sustainability of competitive advantage. The Academy of Management Perspectives, 22(2), 34-56. https://doi.org/10.5465/AMP.2008.32739758

Rajan, R., Servaes, H., \& Zingales, L. (2000). The cost of diversity: The diversification discount and inefficient investment. The Journal of Finance, 55(1), 35-80. https://doi.org/10.1111/0022-1082.00200

Ransbotham, S., \& Mitra, S. (2010). Target age and the acquisition of innovation in high-technology industries. Management Science, 56(11), 2076-2093. https://doi.org/10.1287/mnsc.1100.1223

Rothaermel, F. T., Kotha, S., \& Steensma, H. K. (2006). International market entry by US internet firms: An empirical analysis of country risk, national culture, and market size. Journal of Management, 32(1), 56-82. https://doi.org/10.1177/0149206305277793

Schmalensee, R. (2000). Antitrust issues in Schumpeterian industries. American Economic Review, 90(2), 192-196. https://doi.org/10.1257/aer.90.2.192

Shenkar, O. (2001). Cultural distance revisited: Towards a more rigorous conceptualization and measurement of cultural differences. Journal of International Business Studies, 32(3), 519-535. https://doi.org/10.1057/palgrave.jibs.8490982

Shin, H. H., \& Stulz, R. M. (1998). Are internal capital markets efficient? The Quarterly Journal of Economics, 113(2), 531-552.https://doi.org/10.1162/003355398555676

Stahl, G. K., \& Tung, R. L. (2015). Towards a more balanced treatment of culture in international business studies: The need for positive cross-cultural scholarship. Journal of International Business Studies, 46(4), 391-414. https://doi.org/10.1057/jibs.2014.68

Stein, J. C. (1997). Internal capital markets and the competition for corporate resources. The Journal of Finance, 52(1), 111-133. https://doi.org/10.1111/j.1540-6261.1997.tb03810.x 
Stern, I., \& Henderson, A. D. (2004). Within-business diversification in technology-intensive industries. Strategic Management Journal, 25(5), 487-505. https://doi.org/10.1002/smj.400

Tanriverdi, H., \& Lee, C. H. (2008). Within-industry diversification and firm performance in the presence of network externalities: Evidence from the software industry. Academy of Management Journal, 51(2), 381-397. https://doi.org/10.5465/AMJ.2008.31767300

Tanriverdi, H., \& Venkatraman, N. (2005). Knowledge relatedness and the performance of multibusiness firms. Strategic Management Journal, 26(2), 97-119. https://doi.org/10.1002/smj.435

Trompenaars, F., \& Hampden-Turner, C. (1997). Riding the waves of culture. Understanding cultural diversity in business. London, UK: Nicholas Brealey Publishing.

Uhlenbruck, K., Hitt, M. A., \& Semadeni, M. (2006). Market value effects of acquisitions involving internet firms: A resource based analysis. Strategic Management Journal, 27(10), 899-913. https://doi.org/10.1002/smj.546.

Vanagtmael, A. W., \& Errunza, V. R. (1982). Foreign portfolio investment in emerging securities markets. Columbia Journal of World Business, 17(2), 58-63.

Vermeulen, F., \&Barkema, H. (2001). Learning through acquisitions. Academy of Management Journal, 44(3), 457-476. https://doi.org/10.2307/3069364

Warner, A. G., Fairbank, J. F., \& Steensma, H. K. (2006). Managing uncertainty in a formal standards-based industry: A real options perspective on acquisition timing. Journal of Management, 32(2), 279-298. https://doi.org/10.1177/0149206305280108

Zaheer, A., Castaner, X., \& Souder, D. (2005). Complementarity, similarity, and value creation in mergers and acquisitions. Paris, FR: Cahier de Recherche du Groupe HEC.

Zaheer, S. (1995). Overcoming the liability of foreignness. Academy of Management Journal, 38(2), 341-363. https://doi.org/10.2307/256683

Zhao, H., Luo, Y., \& Suh, T. (2004). Transaction cost determinants and ownership-based entry mode choice: A meta-analytical review. Journal of International Business Studies, 35(6), 524-544. https://doi.org/10.1057/palgrave.jibs.8400106

\section{Copyrights}

Copyright for this article is retained by the author(s), with first publication rights granted to the journal.

This is an open-access article distributed under the terms and conditions of the Creative Commons Attribution license (http://creativecommons.org/licenses/by/4.0/). 